\title{
Aktywność spływów gruzowych w polskiej części Karkonoszy w świetle badań lichenometrycznych
}

\author{
The activity of debris flows in the Polish part of the Karkonosze Mountains \\ in the light of lichenometric measurements
}

\author{
STANISEAW KĘDZIA \\ Instytut Geografii i Przestrzennego Zagospodarowania im. Stanisława Leszczyckiego, \\ Polska Akademia Nauk \\ 31-018 Kraków, ul. św. Jana 22; kedzia@zg.pan.krakow.pl
}

\section{KRZYSZTOF PARZÓCH}

Instytut Geografii i Rozwoju Regionalnego, Uniwersytet Wrocławski 50-137 Wrocław, Pl. Uniwersytecki 1; krzysztof.parzoch@uwr.edu.pl

Zarys treści. W latach 2011-2012 oraz 2014 r. prowadzono datowania lichenometryczne form utworzonych przez spływy gruzowe w karkonoskich kotłach polodowcowych: Wielkim Śnieżnym Kotle, Czarnym Kotle Jagniątkowskim, Kotle Małego Stawu, Kotle Łomniczki oraz niszy niwalnej Białego Jaru. Celem tych pomiarów było zbadanie aktywności spływów gruzowych w ostatnich 150 latach. Na podstawie przeprowadzonego datowania lichenometrycznego wydzielono trzy fazy aktywności spływów gruzowych w Karkonoszach. Pierwszą fazę, związaną z małą epoką lodową, charakteryzowała duża aktywność badanych procesów. Zakończyła się ona, podobnie jak w Tatrach, w latach 1920. Po niej nastał okres względnego spokoju, przerywany niewielką liczbą epizodów występowania spływów w latach 1930., 1940. i w roku 1964. Kolejna faza wzmożonej aktywności transportu materiału skalnego w obrębie form utworzonych przez spływy, włączając również nowe spływy gruzowe, rozpoczęła się w latach 1980. i trwa do dziś.

Słowa kluczowe: cyrki polodowcowe, spływy gruzowe, datowanie lichenometryczne, Karkonosze.

\section{Wstęp}

Spływy gruzowe są jednym z ważniejszych procesów modelujących karkonoskie stoki powyżej górnej granicy lasu (Bieroński i inni, 1992). Najwięcej tego typu procesów zachodzi na stromych stokach kotłów polodowcowych. Prowadzone w latach 2001-2005 szczegółowe kartowanie geomorfologiczne pozwoliło zidentyfikować w polskiej części Karkonoszy 70 form utworzonych przez spływy 
gruzowe (Parzóch i inni, 2007). Najwięcej takich form, bo aż 27, znajduje się w Kotle Łomniczki. W Kotle Małego Stawu występuje 16, w Kotle Dużego Stawu 10, w Małym i Wielkim Śnieżnym Kotle 11, natomiast w Czarnym Kotle Jagniątkowskim tylko 2 formy. Pozostałe 4 spływy skartowano na zboczach niektórych dolin i stromych, górnych partiach grzbietów (Parzóch i inni, 2007). Warto w tym miejscu dodać, że szlaków spływowych w Karkonoszach z pewnością jest więcej, na co wskazują analizy z wykorzystaniem ortofotomap i danych pochodzących ze skaningu laserowego LIDAR (Migoń i Parzóch, 2010). Z 70 skartowanych form znany i opisany w literaturze jest wiek tylko 14. Najstarsze z zarejestrowanych i opisanych spływów wystąpiły w 1964 r., następne w latach 1994, 1997, 2001, 2002 oraz 2006 (Czerwiński, 1967; Migoń i inni, 2002; Parzóch i Dunajski, 2002; Szymanowski, 2004; Migoń i inni, 2006; Migoń i Parzóch, 2008). Ostatnim zarejestrowanym epizodem tego typu ruchów masowych w polskich Karkonoszach był spływ gruzowy na północnym stoku Śnieżki w lipcu 2009 r. (Parzóch i Knapik, 2009).

W 2012 r. przeprowadzono datowania lichenometryczne w Kotle Łomniczki. Najstarsze plechy znalezione wówczas na powierzchni formy, utworzonej przez spływy gruzowe wydatowano na przełom XIX i XX w. (prawdopodobnie rok 1897 lub 1903), czyli z końca małej epoki lodowej, charakteryzującej się w Karkonoszach, podobnie jak w Tatrach, dużym natężeniem występowania spływów gruzowych (Pilous, 1973, 1975, 1977; Czerwiński, 1991). Brak starszych plech bynajmniej nie musi oznaczać, że badana forma nie mogła powstać znacznie wcześniej. W miarę upływu czasu ekspansja roślinności (Dunajski, 1998) i procesy stokowe - głównie późniejsze spływy gruzowe, zacierają ślady wcześniejszych zdarzeń. Kolejnymi latami, które zaznaczyły się powstaniem w Kotle Łomniczki nowych spływów gruzowych lub przemodelowaniem już istniejących, były lata 1920. (prawdopodobnie 1926 r.), 1940., 1960. (1964 r.), 1980., 1990. (rok 1994 i 1997) ubiegłego oraz pierwsze lata obecnego wieku. Wyniki datowań lichenometrycznych w Kotle Łomniczki (Kędzia i Parzóch, 2013) dowodzą, że każda z badanych form odznacza się inną historią. Niektóre zostały utworzone podczas jednego zdarzenia i nie podlegały przemodelowaniu podczas następnych zdarzeń, lub to przemodelowanie ograniczało się tylko do przemieszczenia niewielkiej ilości materiału na bardzo krótkim odcinku.

W 2014 roku przeprowadzono datowania lichenometryczne form utworzonych przez spływy gruzowe w następujących kotłach polodowcowych Karkonoszy: Wielkim Śnieżnym Kotle, Czarnym Kotle Jagniątkowskim, Kotle Małego Stawu oraz Białym Jarze, będącym niszą niwalną (ryc. 1). O wyborze miejsca badań decydowało występowanie spływów gruzowych o znanej dacie powstania, które miały służyć do skalibrowania tempa przyrostu plech. Badania miały na celu określenie wieku form i wyznaczenie okresów wzmożonej aktywności spływów gruzowych oraz procesów morfogenetycznych w obrębie form utworzonych przez spływy. 


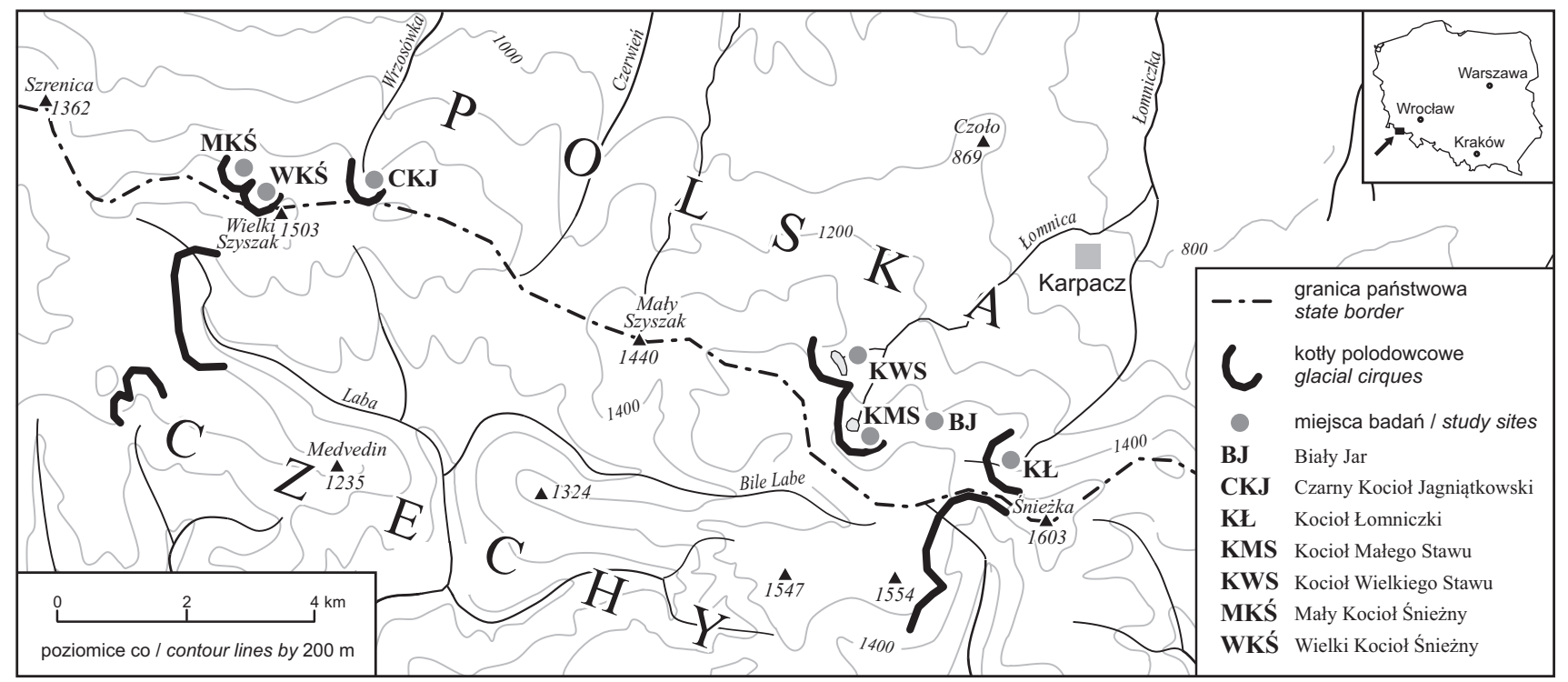

Ryc. 1. Szkic lokalizacyjny z zaznaczonymi miejscami badań A localization sketch with the study sites

Opracowanie własne / Authors' own elaboration. 


\section{Obszar badań}

Głównymi składowymi rzeźby Karkonoszy, najwyższego masywu Sudetów, są wyraźnie zaznaczone zrównania wierzchowinowe oraz strome stoki głównego grzbietu, rozcięte głębokimi dolinami rzecznymi (Migoń, 2005). Istotnym elementem rzeźby karkonoskiej są także pozostałości górskich zlodowaceń plejstoceńskich w postaci kotłów polodowcowych i wałów morenowych. W Karkonoszach polskich znajduje się 6 kotłów, od zachodu: Kotły Wielki Śnieżny i Mały Śnieżny, Czarny Kocioł Jagniątkowski, Kocioł Wielkiego Stawu, Kocioł Małego Stawu oraz Kocioł Łomniczki. Ponadto północne stoki głównego grzbietu Karkonoszy podcięte są niszami źródliskowymi, których pierwotne założenia związane są z działalnością procesów niwalnych w plejstocenie. Od zachodu są to: tzw. Kocioł Szrenicki, Kocioł Łabski, Kocioł Smogorni oraz Biały Jar (m.in. Czerwiński, 1985).

Badane cyrki polodowcowe wraz z niszą niwalną Białego Jaru usytuowane są na północnym skłonie Karkonoszy między szczytem Śnieżki (1602 m n.p.m.) na wschodzie, a Łabskim Szczytem (1470 m n.p.m.) na zachodzie. Są one otwarte w kierunku północnym lub północno-wschodnim. Ich dna, położone powyżej 1100 m n.p.m., najczęściej otaczają skalne ściany, porozcinane rynnami korazyjnymi, u wylotów których znajdują się stożki usypiskowo-obrywowe. Wszystkie badane formy zostały wyżłobione przez lodowce oraz płaty firnowo-lodowe w granicie karkonoskim. Ostatnie lodowce wytopiły się w Venedigerze nieco ponad 8 tys. lat temu (Wicik, 1986; Chmal i Traczyk, 1998; Engel i inni, 2011).

Ze względu na duże zacienienie i zwiększoną akumulację śniegu (lawiny, nawiewanie) cyrki polodowcowe odznaczają się odmiennym w stosunku do pozostałych stoków topoklimatem. Płaty śnieżne zalegają w zagłębieniach w obrębie ścian kotłów i u ich podnóża nierzadko nawet do sierpnia (Kwiatkowski, 1985; Sobik i inni, 2013).

\section{Metoda}

Do datowania lichenometryczne wykorzystano porosty naskalne z grupy Rhizocarpon. Do kreślenia wieku plech posłużyła krzywa lichenometryczna wyznaczona przez S. Kędzię (2011). Ponieważ topoklimat kotłów polodowcowych różni się od klimatu szczytowo-grzbietowych partii Karkonoszy, dla których została wyznaczona krzywa lichenometryczna, wskaźnik przyrostu plech skalibrowano przy użyciu plech pomierzonych na spływach gruzowych o znanej dacie powstania. Takimi reperowymi formami były spływy z 1997 r. w Kotle Małego Stawu oraz w Czarnym Kotle Jagniątkowskim. Spływu w Białym Jarze, zgodnie z zasadami datowania lichenometrycznego, nie uznano za reperowy ze względu na płynący w nim potok i wpływ jego wody na przyrost plech. Pomiary wykaza- 
ły, że wskaźnik przyrostu plech w badanych kotłach polodowcowych różni się od wskaźnika wyznaczonego przez S. Kędzię (2011) dla szczytowo-grzbietowych partii Karkonoszy. Podobna sytuacja miała miejsce w przypadku datowania lichenometrycznego w Kotle Łomniczki (Kędzia i Parzóch, 2013). Na skutek różnicy topoklimatu oraz dużego wpływu roślinności (większość badanych spływów w Kotle Łomniczki usytuowana jest lesie) wskaźnik przyrostu plech w badanym kotle był około dwukrotnie większy niż wynikało to z krzywej lichenometrycznej opracowanej dla części szczytowo-grzbietowej. O ile w Kotle Łomniczki przyrost plech można było skalibrować na formach powstałych w różnych latach (1964 i 1994), o tyle w badanych kotłach istniały tylko repery sprzed zaledwie 17 lat. Im starsze repery i większa różnica czasowa w dacie ich powstania, tym dokładność wyznaczenia wskaźnika przyrostu jest większa. W przypadku reperów liczących kilkanaście lat, nawet niewielki błąd pomiaru potęguje się i w efekcie datowanie, zwłaszcza starszych form, staje się mniej precyzyjne. Z tego powodu wskaźnik przyrostu plech dla badanych kotłów dla wysokości 1100 m n.p.m. został przez autorów niniejszej pracy oszacowany, na podstawie tempa przyrostu plech na formach o znanej dacie powstania, w przybliżeniu na około $70 \mathrm{~mm}$ na 100 lat. Obiektów reperowych w postaci form o znanej dacie powstania było zbyt mało, aby określić zmienność tempa przyrostu. Autorzy założyli więc jego stałe tempo przyrostu oraz spadek wskaźnika przyrostu wraz ze wzrostem wysokości, zgodnie do krzywej lichenometrycznej wyznaczonej przez S. Kędzię (2011, 2015). Autorzy na podstawie pomiarów przeprowadzonych w cyrkach polodowcowych na najmłodszych formach pospływowych o znanej dacie powstania ocenili, że plechy potrzebują około 4-6 lat, żeby skolonizować świeżą powierzchnię skalną i osiągnąć średnicę 2-3 mm, umożliwiającą jej w miarę precyzyjne zmierzenie. Największy procentowy błąd pomiarowy występuje przy małych plechach. Mierząc plechę o średnicy $2,5 \mathrm{~mm}$ z dokładnością około $0,5 \mathrm{~mm}$ błąd pomiaru sięga $20 \%$ średnicy plechy. Przy plechach większych procentowy błąd pomiaru ulega zmniejszeniu.

Oszacowany wskaźnik przyrostu plech dla badanych kotłów jest o około $13 \mathrm{~mm}$ mniejszy niż w Kotle Łomniczki (Kędzia i Parzóch, 2013). Różnica ta prawdopodobnie wynika nie tylko z dużego wpływu roślinności na szybkość przyrostu plech w Kotle Łomniczki, ale również ze względu na niższy stopień zanieczyszczenia powietrza. W kotle tym plechy porostu Rhizocarpon występowały liczniej niż w pozostałych kotłach, w których prowadzono datowania lichenometryczne. Według badań prowadzonych przez M. Kossowską (2013) oraz S. Schwarzak i innych (2014), najmniej zanieczyszczeń dociera właśnie do Kotła Łomniczki.

Pomiaru plech dokonywano za pomocą przeźroczystego przymiaru kreskowego z dokładnością około $0,5 \mathrm{~mm}$. Plechy porostów mierzono na całej powierzchni form utworzonych przez spływy gruzowe: w dnie rynien, na wałach oraz łapach. Łącznie we wszystkich omawianych w tej pracy kotłach (łącznie z Kotłem Łomniczki) i niszy niwalnej pomierzono 269 plech. Przy wyznaczaniu wieku bada- 
nych form posłużono się tą samą metodą co przy tworzeniu krzywej lichenometrycznej dla Karkonoszy, czyli pomiarze 5 największych plech z zastosowaniem modyfikacji opisanej przez S. Kędzię (Kędzia, 2013a,b, 2015). Do lokalizacji form posłużono się odbiornikiem GPS Garmin Oregon 200 (z aktywnym WAAS), którego maksymalny błąd wskazań na badanym obszarze sięgał około 4-10 m.

\section{Wyniki}

\section{Wielki Śnieżny Kocioł}

Pomiary lichenometryczne prowadzono na 6 stożkach usypiskowo-obrywowych (ryc. 2). Datowano głównie formy utworzone przez spływy gruzowe. Mimo że w Wielkim Śnieżnym Kotle znajdują się dwie formy utworzone przez spływy gruzowe w 1997 i 2006 r., nie można ich było użyć jako obiektów reperowych, ze względu na brak plech lub ich znikomą ilość.

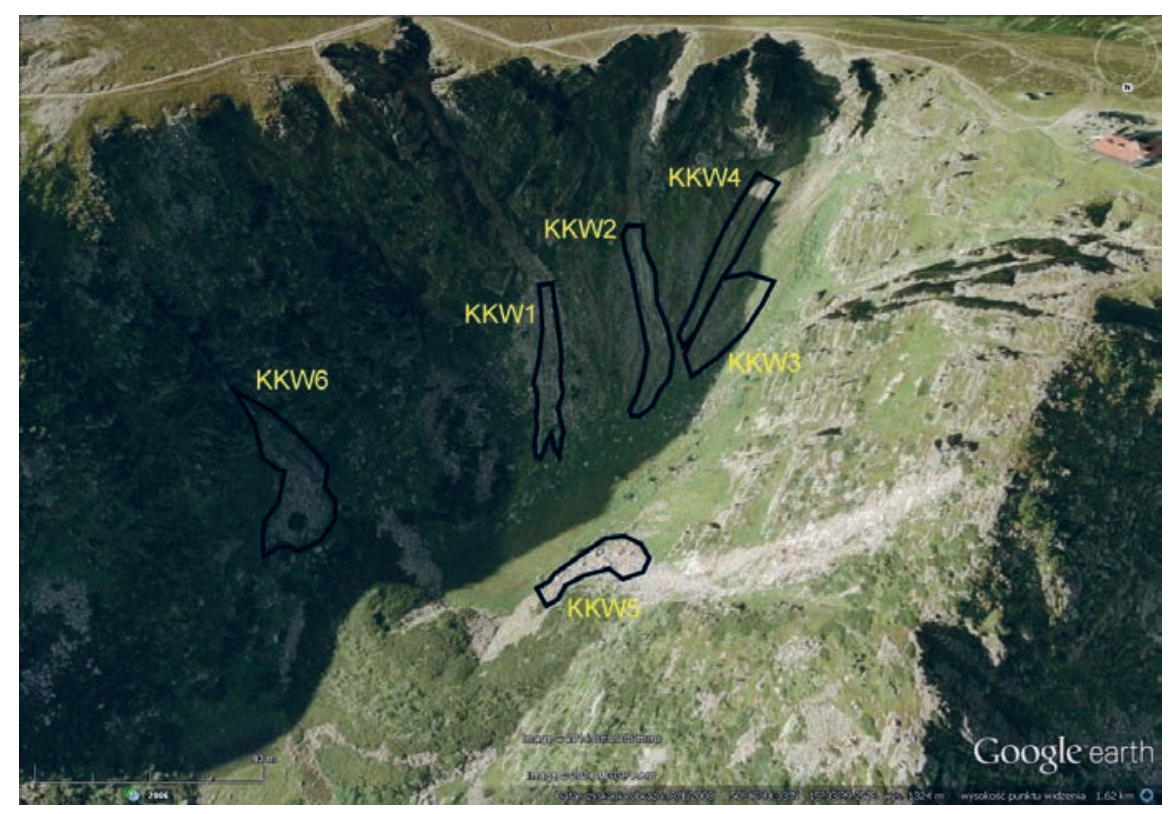

Ryc. 2. Wielki Śnieżny Kocioł z zaznaczonymi powierzchniami pomiarowymi Wielki Śnieżny Glacial Cirque with marked measuring sites

Na powierzchni stożka oznaczonego jako KKW6 pomierzono kilkanaście plech o średnicach 100-120 mm, które prawdopodobnie pochodzą z drugiej połowy XIX w., czyli z małej epoki lodowej. Nie były to jednak najstarsze plechy, tylko największe jakie można było pomierzyć zgodnie z przyjętymi zasadami datowa- 
nia metodą lichenometryczną. U wylotu żlebu znajdowało się sporo świeżego, drobnego materiału, nie pokrytego plechami. Niewielkie ilości świeżego materiału znajdowały się również w środkowej i dolnej części badanego stożka.

Kolejne pomiary lichenometryczne przeprowadzono na stożku oznaczonym jako KKW1. W 2006 r. powstał na nim duży spływ gruzowy o długości około $190 \mathrm{~m}$. Niestety, na materiale naniesionym przez ów spływ nie znaleziono plech, które mogłyby zostać użyte do pomiarów. Natomiast na sąsiedniej, starszej formie utworzonej przez spływ gruzowy, pomierzono niewielką liczbę plech (8 sztuk) o średnicy z przedziału 37-43 mm, które prawdopodobnie pochodzą z lat 1960.

Następne pomiary lichenometryczne przeprowadzono na formie utworzonej przez spływ w 1997 r., znajdującej się na stożku oznaczonym jako KKW2. Niestety również na tej formie, podobnie jak na sąsiedniej z 2006 r., nie znaleziono odpowiednich plech do datowania. W świeżym i drobnym materiale pozbawionym plech znajdowała się niewielka ilość starszego materiału ze sporadycznie występującymi plechami, jednak zbyt nielicznymi, aby móc przypisać im jakiś przedział czasowy. Trudno wiarygodnie uzasadnić brak plech na formach utworzonych w 1997 i $2006 \mathrm{r}$.

Na stożku oznaczonym jako KKW3 przeprowadzono pomiary lichenometryczne na starej, ale bardzo wyraźnej formie, utworzonej przez spływ gruzowy. Na głazach tworzących wały występowały dosyć licznie duże plechy o maksymalnej średnicy do około $60 \mathrm{~mm}$, które można wiązać z latami 1920. (prawdopodobnie z rokiem 1926). Natomiast materiał tworzący powierzchnię stożka porastały plechy o maksymalnej średnicy rzędu 100-120 mm, pochodzące z drugiej połowy XIX w. Podobnie jak na KKW6 nie były to najstarsze plechy, lecz największe jakie można było pomierzyć zgodnie z zasadami tej metody datowania. Oprócz starego materiału występowała również niewielka ilość świeżego materiału z małymi plechami, lub nawet bez plech.

Na sąsiedniej formie pospływowej, oznaczonej symbolem KKW4, zmierzono kilkanaście plech o średnicy dochodzącej do $60 \mathrm{~mm}$, które podobnie jak na wcześniejszej formie KKW3, najprawdopodobniej pochodzą z lat 1920. Na powierzchni badanej formy znajdowała się również niewielka ilość świeżego materiału bez plech.

Ostatnią formą datowaną lichenometrycznie był stożek usypiskowo-obrywowy oznaczony symbolem KKW5. Wśród świeżego materiału pozbawionego plech występowały również głazy z plechami o średnicy około $6 \mathrm{~mm}$ (prawdopodobnie z 2006 r.) i nieco starsze z plechami około $15 \mathrm{~mm}$ z lat 1990. (prawdopodobnie z 1994 r.).

Datowanie w Wielkim Śnieżnym Kotle należało do najtrudniejszych i najmniej dokładnych ze względu na brak plech na spływach o znanej dacie powstania. Zastanawiająca jest również duża dysproporcja w ilości plech na starych formach z małej epoki lodowej (głównie z jej końca i drugiej połowy XX w.), a formach młodych. Wszelkie daty podane z dokładnością do jednego roku należy trakto- 
wać wyłącznie orientacyjnie. Są one próbą przypisania plechom, których data pojawienia się na danej formie została oszacowana z dokładnością do około 10, a w przypadku starych plech około 20 lat, konkretnych znanych ekstremalnych zdarzeń hydrometeorologicznych, powodujących powstanie spływów gruzowych.

\section{Czarny Kocioł Jagniątkowski}

W Czarnym Kotle Jagniątkowskim, podobnie jak w Kotle Małego Stawu, datowanie lichenometryczne przeprowadzono na formie, która w ostatnim czasie najsilniej została przemodelowana przez spływ gruzowy w 1997 r. i właśnie z tego zdarzenia jest najwięcej plech o średnicy około $12 \mathrm{~mm}$ (ryc. 3). 10 plech o średnicy rzędu 35-40 mm zachowało się również z lat 1960., występują one głównie na wałach po obu stronach rynny. Na grzbietach tych wałów i po ich zewnętrznej stronie znaleziono kilka dużych plech o średnicy 60-65 mm, które przypuszczalnie pochodzą z drugiej lub trzeciej dekady XX w., czyli końca małej epoki lodowej. Forma ta powstała więc najpóźniej pod koniec małego glacjału i została przemodelowana zapewne w 1964 r. przez niewielki spływ gruzowy, a następnie mocno zmieniona przez spływ w 1997 r. W środkowej części rynny znaleziono, podobnie jak w Kotle Małego Stawu, kilka plech o średnicy rzędu 6-7 mm, odpowiadającej początkowi XXI w., które prawdopodobnie są zapisem niewielkiego przemieszczenia się materiału w dnie rynny w roku 2006.

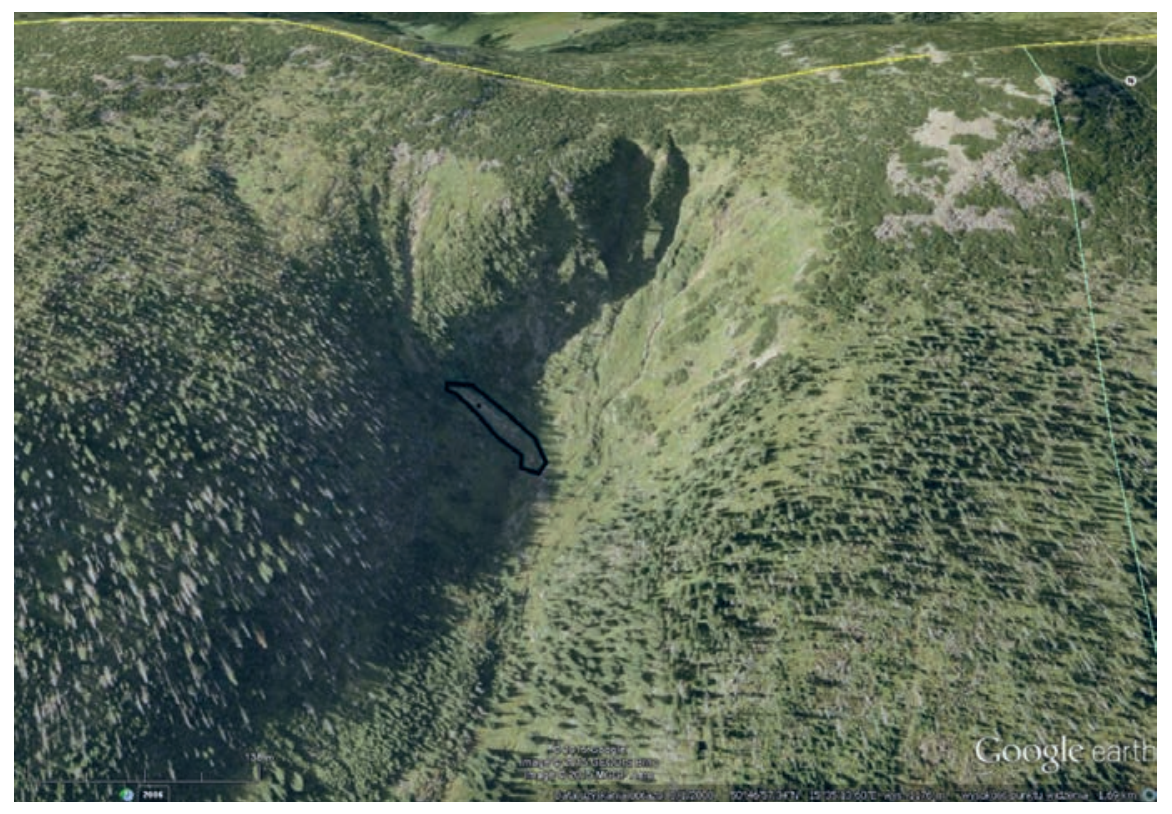

Ryc. 3. Czarny Kocioł Jagniątkowski z zaznaczoną powierzchnią pomiarową Czarny Jagniątkowski Glacial Cirque with marked measuring site 


\section{Kocioł Małego Stawu}

W Kotle Małego Stawu pomiary lichenometryczne przeprowadzono na formie silnie przemodelowanej przez spływ w 1997 r. (ryc. 4). Pierwsze pomiary wykonano w 2011 r., następne w 2014. Różnica wielkości plech po upływie trzech lat była trudna do wychwycenia wskutek małego przyrost plech i zróżnicowania tempa przyrostu, związanego między innymi z wysokością. Samo datowanie nie było ani precyzyjne, ani łatwe, ze względu na małą ilość plech. Oprócz roku 1997, w którym doszło do dużego przemodelowania formy, zaznaczyły się również zdarzenia z innych lat. Bardzo nieliczne stare plechy wydatowano na lata 1930., 1960. (prawdopodobnie 1964 r.) i 1980. W wymienionych okresach doszło do przemieszczenia się materiału w omawianej formie. Trudno dzisiaj ocenić jak duże były te przemieszczenia, ponieważ późniejsze zdarzenia, głównie spływ w 1997 r., zatarły wiele śladów. Najwięcej plech zachowało się z lat 1990. Część z nich prawdopodobnie jest zapisem przemieszczenia się materiału w roku 1994, natomiast reszta (większa część) pochodzi z materiału przemieszczonego w czasie dużego spływu w 1997 r. Wzdłuż całego profilu, ale głównie w dolnej części formy, wielokrotnie pomierzono plechy o średnicy około $6 \mathrm{~mm}$, które można wiązać z niewielkimi przemieszczeniami materiału w 2006 r.

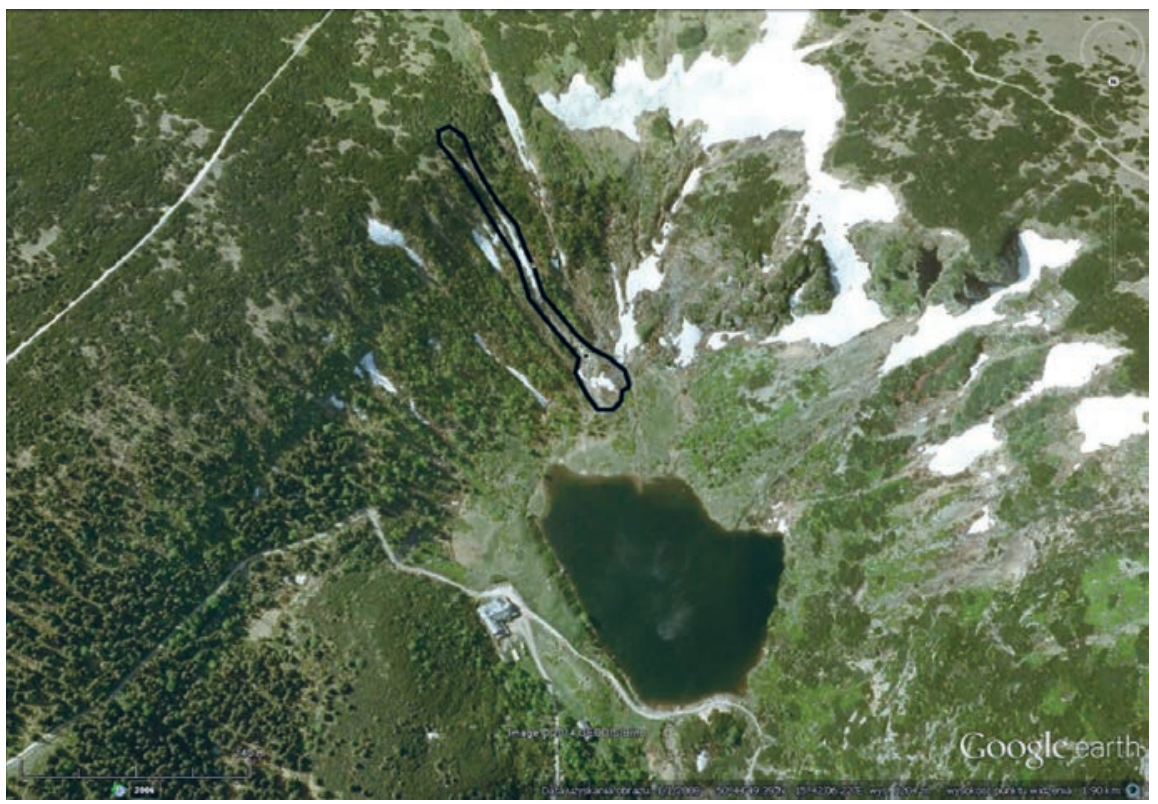

Ryc. 4. Kocioł Małego Stawu z zaznaczoną powierzchnią pomiarową Mały Staw Glacial Cirque with marked measuring site 
Sąsiednie formy po spływach gruzowych były zbyt zarośnięte roślinnością, aby móc przeprowadzić poprawne datowanie lichenometryczne. Jednakże na niektórych dużych głazach usytuowanych w pokrytych glebą i murawami wałach oraz rynnie starego spływu gruzowego, sąsiadującego od północy z opisanym spływem z 1997 r., znaleziono plechy przynajmniej 100-letnie. Są one zapewne zapisem zdarzeń z drugiej połowy XIX w.

\section{Biały Jar}

W 1997 r. w Białym Jarze doszło do spływu gruzowego, który utworzył w dnie doliny duży stożek torencjalny o długości około $40 \mathrm{~m}$ i powierzchni około $300 \mathrm{~m}^{2}$ (ryc. 5, Migoń i Parzóch, 2008). Obecnie spora część tej formy jest pokryta roślinnością, co uniemożliwia datowanie lichenometryczne. Na odsłoniętym materiale gruzowym w kilku miejscach występują plechy o średnicy około 10-11 mm, które uznano za zapis wspomnianego wyżej zdarzenia. Starsze plechy występują bardzo rzadko i ze względu na kształt oraz łączenie się plech odstąpiono od ich datowania. Nie udało się również znaleźć odpowiedniej liczby plech świadczących o przemieszczaniu się materiału w okresie późniejszym niż 1997 rok. Datowanie w niszy Białego Jaru było utrudnione nie tylko z powodu zarastania starszych form, lecz również ze względu na obecność wody potoku, która wpływa na tempo przyrostu plech.

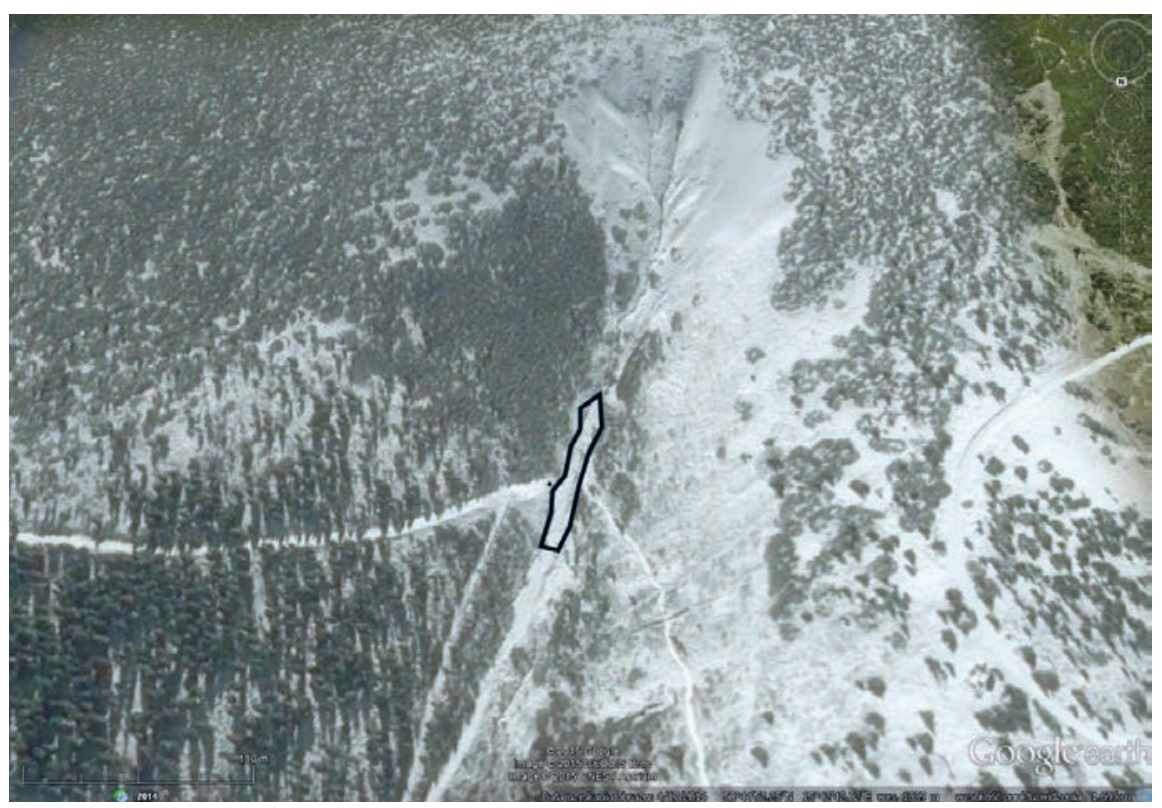

Ryc. 5. Biały Jar z zaznaczoną powierzchnią pomiarową Biały Jar with marked measuring site 


\section{Dyskusja}

Datowanie lichenometryczne form utworzonych przez spływy gruzowe w kotłach polodowcowych w polskiej części Karkonoszy było utrudnione, głównie ze względu na specyficzne uwarunkowania topoklimatyczne kotłów, dużą ekspansję roślinności (zwłaszcza na formach położonych poniżej górnej granicy lasu), oraz czasowe i przestrzenne zróżnicowanie zanieczyszczeń powietrza. W niektórych przypadkach datowanie lichenometryczne było bardziej zbliżone do szacowania niż konkretnego określania wieku formy, głównie za sprawą braku odpowiednich obiektów reperowych. Mimo wyżej wymienionych trudności udało się określić daty lub przedziały czasowe aktywności spływów gruzowych, oraz przemieszczeń materiału w obrębie form utworzonych przez te spływy. W tabeli 1 zamieszczono dla badanych kotłów polodowcowych i niszy niwalnej Białego Jaru przedziały czasowe z datami, w których doszło do powstania spływów gruzowych lub przemieszczeń materiału. Dokładne daty powstania niektórych spływów gruzowych są znane i opisane w literaturze, dotyczy to głównie

Tabela 1. Okresy aktywności spływów gruzowych i późniejszych przemieszczeń materiału w obrębie form utworzonych przez spływy

Periods of activity of debris flows and further displacement of material within landforms created by them

\begin{tabular}{|l|c|c|c|c|c|}
\hline \multicolumn{1}{|c|}{$\begin{array}{c}\text { Czas } \\
\text { Time }\end{array}$} & $\begin{array}{c}\text { Wielki } \\
\text { Śnieżny } \\
\text { Kocioł }\end{array}$ & $\begin{array}{c}\text { Czarny } \\
\text { Kocioł } \\
\text { Jagniątkowski }\end{array}$ & $\begin{array}{c}\text { Kocioł } \\
\text { Małego } \\
\text { Stawu }\end{array}$ & $\begin{array}{c}\text { Biały } \\
\text { Jar }\end{array}$ & $\begin{array}{c}\text { Kocioł } \\
\text { Łomniczki }\end{array}$ \\
\hline $\begin{array}{l}\text { Druga połowa XIX w. } \\
\text { 2nd half of 19th century }\end{array}$ & $\mathrm{T}$ & b.d. & $\mathrm{T}$ & b.d. & $\mathrm{T}$ \\
1900-1930 (1926) & $\mathrm{T}$ & $\mathrm{T}$ & b.d. & b.d. & $\mathrm{T}$ \\
1930-1940 & b.d. & b.d. & $\mathrm{T}$ & b.d. & b.d. \\
1940-1950 & b.d. & b.d. & b.d. & b.d. & $\mathrm{T}$ \\
$1950-1960$ & b.d. & b.d. & b.d. & b.d. & b.d. \\
$1960-1970$ (1964) & T & T & T & b.d. & T \\
$1970-1980$ & b.d. & b.d. & b.d. & b.d. & b.d. \\
$1980-1990$ & b.d. & b.d. & T & b.d. & T \\
$1990-2000$ (1994 i 1997) & T & T & T & T & T \\
$2001-2002$ & b.d. & b.d. & b.d. & b.d. & T \\
2006 & T & T & T & b.d. & T \\
\hline
\end{tabular}

$\mathrm{T}$ - wystąpienie spływu lub niewielkie przemieszczenie materiału / occurrence of a debris flow or slight movement of material;

b.d. - brak spływów lub brak danych / no debris-flow episodes or lack of data.

Opracowanie własne. / Author's own elaboration. 
lat 1964, 1994, 1997, 2001-2002, 2006 (Czerwiński, 1967; Parzóch i Dunajski, 2002; Migoń i inni, 2006; Parzóch i inni, 2007; Migoń i Parzóch, 2008). Dla niektórych form powstałych w ostatnich 50 latach za pomocą datowania lichenometrycznego wyznaczono z dokładnością do kilku lat przedział czasowy, w którym dane zdarzenie miało miejsce. Przypisanie tym zdarzeniom konkretnych dat nie stanowiło problemu. Natomiast pozostałym formom, głównie starszym, dla których ów przedział czasowy był znacznie szerszy, dużo trudniej było przypisać jedno zdarzenie. Dla niektórych przedziałów czasowych nie ma w literaturze opisów żadnych zdarzeń w postaci spływów gruzowych, co nie oznacza, że nie doszło do mniejszych lub większych przemieszczeń w obrębie samych form, utworzonych wcześniej przez spływy gruzowe.

Mimo że opady deszczu są przestrzennie bardzo zróżnicowane, zarówno pod względem czasu trwania jak i natężenia, lata z zarejestrowanymi spływami gruzowymi w którymś z kotłów polodowcowych zaznaczyły się mniejszym lub większym przemieszczeniem materiału również w formach utworzonych przez spływy w innych kotłach polodowcowych. W sytuacjach, gdy opady nie były dostatecznie intensywne i/lub nie było nagromadzonej dostatecznej ilości materiału do transportu, woda przemieszczała materiał w obrębie utworzonych wcześniej rynien i wałów. Wiele form utworzonych przez spływy gruzowe zarosło roślinnością i nie wykazuje żadnej aktywności. Jednak niektóre, nawet bardzo stare formy, nadal są modelowane przez nowe spływy gruzowe, wykorzystujące już istniejące formy.

W tabeli 1 wymieniono okresy aktywności spływów gruzowych oraz późniejszych przemieszczeń materiału w obrębie form utworzonych przez spływy, dla poszczególnych cyrków polodowcowych i niszy niwalnej. Dwa pierwsze przedziały czasowe, to jest druga połowa XIX w. i pierwsze trzy dekady XX w., charakteryzuje występowanie spływów gruzowych w każdym z badanych cyrków. Świadczy to o dużej aktywności tego typu procesów w wymienionym okresie. Według V. Pilousa $(1973,1975,1977)$ rekordowy pod względem liczby spływów gruzowych był rok 1897, a następnie 1882. W kolejnych trzech przedziałach czasowych, czyli okresie od 1930 do 1960 r. występowanie spływów gruzowych było raczej sporadyczne i dotyczyło tylko dwóch cyrków polodowcowych. Lata 1960., a konkretnie 1964 r., zapisał się spływami gruzowymi, lub znacznymi przemieszczeniami materiału, we wszystkich badanych karach. Być może niektóre przemieszczenia materiału w obrębie badanych form pochodzą z $1968 \mathrm{r}$. Z kolejnego dziesięciolecia nie ma żadnych dat świadczących o występowaniu spływów gruzowych. Od lat 1980. notowany jest wzrost liczby tego typu zdarzeń geomorfologicznych. Szczególnie duża aktywność procesów morfogenetycznych w obrębie stoków gruzowych charakteryzuje ostatnie dwa dziesięciolecia.

Porównując zamieszczone w tabeli 1 okresy aktywności spływów gruzowych w poszczególnych cyrkach polodowcowych z liczbą spływów opisanych w literaturze przez V. Pilousa (1973, 1975, 1977), J. Czerwińskiego (1967, 1991) czy P. Migonia i innych (2002), widać sporą różnicę liczby tego typu zdarzeń. 
W kronikach i publikacjach naukowych opisane zostały głównie spływy gruzowe, i to prawdopodobnie nie wszystkie. Brak natomiast jest informacji o mniej okazałych zdarzeniach, polegających na przemieszczeniu materiału w obrębie już istniejących form utworzonych przez spływy gruzowe, ale bez większego ich przemodelowania. A jak wynika z datowania lichenometrycznego, do przemieszczeń materiału w obrębie omawianych form dochodziło częściej niż do spływów gruzowych. Datowania lichenometryczne są więc bardzo istotnym, a czasami jedynym źródłem wiedzy o aktywności spływów gruzowych.

Spływy gruzowe w polskiej części Karkonoszy charakteryzuje podobny przebieg aktywności jak spływy gruzowe w Tatrach (Kotarba, 2004; Gądek i inni, 2016). Natomiast w stosunku do wyników I. Malika i P. Owczarka (2009) dotyczących Sudetów Wschodnich, ostatni okres aktywności spływów gruzowych w Karkonoszach prawdopodobnie zaczął się o jedną dekadę później.

\section{Wnioski}

Wyznaczenie faz aktywności spływów gruzowych dla polskiej części Karkonoszy było utrudnione, ze względu na szybkie zarastanie roślinnością form utworzonych przez spływy gruzowe. Liczne stare formy, które nie zarosły, zostały również w dużym stopniu przemodelowane przez późniejsze spływy lub inne formy transportu stokowego i trudno dzisiaj odtworzyć ich wcześniejszą historię.

Jednakże na podstawie do tej pory zbadanych form można wyróżnić trzy fazy aktywności spływów gruzowych. Pierwszą jest mała epoka lodowa, której koniec pod względem zwiększonej aktywności spływów gruzowych można, podobnie jak w Tatrach, przypisać do lat 1920. Charakteryzowała ją duża aktywność omawianych procesów. Na wielu stokach w kotłach polodowcowych udział powierzchni przekształconych przez spływy gruzowe w okresie małej epoki lodowej jest nadal duży. Po małej epoce lodowej nastała faza obniżonej aktywności tego typu procesów, trwająca do lat 1980. Wyjątkiem jest rok 1964 r., w którym w każdym badanym kotle polodowcowym stwierdzono większe lub mniejsze przemieszczenie się materiału. W kilku kotłach również lata 1930. i 1940. zaznaczyły się przemieszczeniem (prawdopodobnie niewielkim) materiału. Dzisiaj nie sposób stwierdzić, czy niektóre przemieszczenia się materiału były spowodowane śnieżnymi lawinami, wodą roztopową połączoną z opadami deszczu, czy też samym deszczem o dużym natężeniu. Ostatnia faza zwiększonej aktywności spływów gruzowych w Karkonoszach rozpoczęła się w latach 1980. Najsilniej w tej fazie zapisały się lata 1990. i pierwsza dekada obecnego wieku.

Uzyskane wyniki pozwalają na stwierdzenie znacznego podobieństwa czasowego między aktywnością spływów gruzowych w Tatrach i Karkonoszach. 
Autorzy artykułu serdecznie dziękują prof. Adamowi Kotarbie za cenne uwagi podczas badań i pisania pracy. Podziękowania kierują również do mgr Roksany Knapik za wsparcie logistyczne i merytoryczne oraz mgr Alicji Kołodziejczyk za pomoc w badaniach terenowych.

\section{Piśmiennictwo}

Bieroński J., Chmal H., Czerwiński J., Klementowski J., Traczyk A., 1992, Wspótczesna denudacja w górskich zlewniach Karkonoszy, Prace Geograficzne, IGiPZ PAN, 155, s. 151-169.

Chmal H., Traczyk A., 1998, Postglacjalny rozwój rzeźby Karkonoszy i Gór Izerskich w świetle analizy osadów rzecznych, jeziornych i stokowych, [w:] J. Sarosiek, J. Štursa (red.), Geoekologiczne Problemy Karkonoszy. Materiaty z sesji naukowej w Przesiece, 15-18.X.1997, t. 1, Wyd. Acarus, Poznań, s. 81-87.

Czerwiński J., 1967, Osuwisko w dolinie Łomniczki w Karkonoszach, Opera Corcontica, 4, s. $169-175$.

Czerwiński J., 1985, Gtówne rysy rzeźby i rozwój geomorfologiczny, [w:] A. Jahn (red.), Karkonosze polskie, Ossolineum, Wrocław, s. 53-76.

Czerwiński J., 1991, Powodzie w rejonie Karkonoszy od XV w. do czasów współczesnych, Acta Universitatis Wratislaviensis, 1237, Prace Instytutu Geograficznego, A6, s. 85-104.

Dunajski A., 1998, Sukcesja roślinności na lawinisku potoku błotno-kamienistego w dolinie Łomniczki w Karkonoszach - stan zaawansowania procesu po trzech latach, Acta Universitatis Wratislaviensis, 2090, Prace Botaniczne, 77, 2.

Engel Z., Traczyk A., Braucher R., Woronko B., Křižek M., 2011, Use of 10Be exposure ages and Schmidt hammer data for correlation of moraines in the Krkonoše Mountains, Zeitschrift für Geomorphologie, 55, 2, s. 175-196.

Gądek B., Grabiec M., Kędzia S., Rączkowska Z., 2016, Reflection of climate changes in the structure and morphodynamics of talus slopes (the Tatra Mountains, Poland), Geomorphology, 263, s. 39-49.

Kędzia S., 2011, Krzywa Lichenomnetryczna porostu naskalnego Rhizocarpon geographicum dla Karkonoszy, Przyroda Sudetów, 14, s. 141-148.

Kędzia S., 2013a, Nowa krzywa lichenometryczna dla polskiej części Tatr, Przegląd Geograficzny, 85, 1, s. 53-63.

Kędzia S., 2013b, Problems and possibilities of lichenometric dating in Polish mountains, Geographia Polonica, 86, 4, s. 363-374.

Kędzia S., 2015, Lichenometric curves for the Polish part of the Karkonosze and Tatra Mountains established with a new method, Zeitschrift für Geomorphologie, 59, 1, s. 103-118.

Kędzia S., Parzóch K., 2013, The activity of debris flows in the Eomniczka Cirque in the light of lichenometric dating, Opera Corcontica, 50/S, s. 75-80.

Kossowska M., 2013, Porosty, [w:] R. Knapik, A. Raj (red.), Przyroda Karkonoskiego Parku Narodowego, Karkonoski Park Narodowy, Jelenia Góra, s. 319-338.

Kotarba A., 2004, Zdarzenia geomorfologiczne w Tatrach Wysokich podczas matej epoki lodowej, Prace Geograficzne, IGiPZ PAN, 197, s. 9-55.

Malik I., Owczarek P., 2009, Dendrochronological records of debris flow and avalanche in a mid-mountain forest zone (Eastern Sudetes - Central Europe), Geochronometria, 34, s. 57-66. 
Migoń P., 2005, Karkonosze - rozwój rzeźby, [w:] M. Mierzejewski (red.), Karkonosze. Przyroda nieożywiona i człowiek, Wydawnictwo Uniwersytetu Wrocławskiego, Wrocław, s. 323-349.

Migoń P., Hradek M., Parzóch K., 2002, Extreme geomorphic events in the Sudetes Mountaiuns and their long-term impact, Studia Geomorphologica Carpatho-Balcanica, 36, s. 29-49.

Migoń P., Kasprzak M., Knapik R., 2006, Sptyw gruzowy w Wielkim Śnieżnym Kotle w sierpniu 2006 r., Przyroda Sudetów, 9, s. 157-168.

Migoń P., Parzóch K., 2008, Sptywy gruzowe w Sudetach, Przegląd Geograficzny, 80, 3, s. 358-401.

Migoń P., Parzóch K., 2008, Geomorfologiczne uwarunkowania przebiegu górnej granicy lasu w Karkonoszach polskich, [w:] A. Mazur, A. Raj, R. Knapik (red.), Monitoring ekosystemów leśnych w Karkonoskim Parku Narodowym, Karkonoski Park Narodowy, Jelenia Góra, s. 29-38.

Migoń P., Parzóch K., 2010, Zdarzenia ekstremalne w systemie stokowym - grawitacyjne ruchy masowe i erozja gleb, [w:] P. Migoń (red.), Wyjątkowe zdarzenia przyrodnicze na Dolnym Ślasku $i$ ich skutki, Rozprawy Naukowe Instytutu Geografii i Rozwoju Regionalnego, 14, Uniwersytet Wrocławski, Wrocław, s. 205-239.

Parzóch K., Dunajski A., 2002, Katastrofalne ruchy masowe w Karkonoskim Parku Narodowym zawiazane z nadmiernymi opadami, [w:] Z. Denisiuk (red.), Strategia zachowania różnorodności biologicznej i krajobrazowej obszarów przyrodniczo cennych dotkniętych klęska powodzi, Instytut Ochrony Przyrody PAN, Kraków, s. 155-165.

Parzóch K., Migoń P., Szymanowski R., Gąsiorek M., 2007, Sptywy gruzowe w pótnocnej części Karkonoszy, [w:] J. Štursa J., R. Knapik (red.), Geoekologické problémy Krkonoš, Sbornik Mezinárodni Vědecké Konferencje, říjen 2006, Svoboda n. Úpou, Opera Corcontica, 44, 1, s. 81-88.

Parzóch K., Knapik R., 2009, Debris flow on NW slope of Mt. Śnieżka, triggered by heavy rainfall on 2 july 2009, [w:] R. Knapik, J. Andrle (red.), 7th International Conference, Geoecological Problems of Karkonosze Mts., Szklarska Poręba, 21-23.09.2009, Book of Abstracts, Karkonoski Park Narodowy, Szklarska Poręba, s. 126.

Pilous V., 1973, Strukturni mury v Krkonoších - I. část, Opera Corcontica, 10, s. 15-69.

Pilous V., 1975, Strukturni mury v Krkonošich - II. část, Opera Corcontica, 12, s. 7-50.

Pilous V., 1977, Strukturni mury v Krkonošich - III. část, Opera Corcontica, 14, s. 7-94.

Schwarzak S., Otop I., Kryza M. (red.), 2014, Projekcje klimatu, zanieczyszczenia powietrza i ładunki krytyczne w regionie granicznym Polski $i$ Saksonii, Sächsisches Landesamt für Umwelt, Landwirtschaft und Geologie, Dresden.

Sobik M., Błaś M., Migała K., Godek M., Nasiółkowski T., 2013, Klimat, [w:] R. Knapik, A. Raj (red.), Przyroda Karkonoskiego Parku Narodowego, Karkonoski Park Narodowy, Jelenia Góra, s. 147-186.

Szymanowski R., 2004, Sptywy gruzowo-błotne w Kotle Łomniczki, Przyroda Sudetów Zachodnich, 7, s. 223-232.

Wicik B., 1986, Asynchroniczność procesów wietrzenia $i$ sedymentacji w zbiornikach jeziornych Tatr $i$ Karkonoszy w postglacjale, Przegląd Geograficzny, 58, 4, s. 809-822.

[Wpłynęło: kwiecień; poprawiono: czerwiec 2016 r.] 


\section{STANISŁAW KĘDZIA, KRZYSZTOF PARZÓCH}

\section{THE ACTIVITY OF DEBRIS FLOWS IN THE POLISH PART OF THE KARKONOSZE MOUNTAINS IN THE LIGHT OF LICHENOMETRIC MEASUREMENTS}

While 70 forms created by debris flows have been mapped for the Polish part of the Karkonosze Mountains, only 14 of these have a known time of origin and have been described in available literature. The oldest registered and described flows occurred in 1964, as followed by further events in 1994, 1997, 2001, 2002 and 2006. In 2011-2012 and 2014. Lichenometric measurements were carried out for the forms created by debris flows in the Karkonosze Mountains, i.e. the Great Snowy Cirque, the Black Cirque of Jagniątków, the Small Tarn Cirque, the Łomniczka Cirque and the White Jar nivation niche, in order to investigate levels of activity over the past 150 years. The lichenometric dating was based around lichens of the Rhizocarpon group. A major obstacle proved to be the limited amounts of lichens, or even their total absence in the case of the youngest forms created by debris flows. An exception was the Łomniczka Cirque. On the basis of the lichenometric dating it proved possible to identify three phases to the activity of Karkonosze debris flows. The first of these was characterised by a high intensity of the processes studied, and was associated with the Little Ice Age. As in the Tatra Mountains, this phase was seen to end in the 1920s, and was followed by a period of relative calm, interspersed with a small number of debris flows in the 1930s and 40s, and then in 1964. The next phase of increased activity as regards the transport of rock material within the forms created by flows (and including new debris flows), began in the 1980s, and has continued through to the present day. The debris flows in the Polish part of the Karkonosze Mountains are thus characterised by a course of activity similar to that noted in the Tatra Mountains. 